\title{
State and prospects for development of livestock products in Russia
}

\author{
Ilgizar Gainutdinov, Farit Mukhametgaliev, Nail Asadullin and Fayaz Avkhadiev
}

Kazan State Agrarian University, Kazan, 420015, Russia

\begin{abstract}
The analysis of the state and level of livestock products development substantiates the need for the development of the beef cattle breeding industry. To improve the efficiency of the industry it is advised to benefit more fully from the available natural lands: pastures and hayfields. Attention is focused on the fact that the efficiency and competitiveness in the market for livestock products are significantly influenced by natural and climatic factors that determine the need for other resources. The statistical method confirmed that the number of farm animals in the Russian Federation compared with the pre-reform period has sharply decreased: cattle - by 3 times, cows - by 2.6 times, pigs - by 1.5 times, sheep and goats - by 2.6 times, which has led to a decrease in livestock density in general and in the productivity of agricultural land. The aim of the research was to consider natural resources in the regions of Russia to increase the livestock of farm animals and increase the volume of dairy and beef cattle breeding, especially beef. The scientific novelty lies in the development of recommendations for the further development of animal breeding in Russia based on the principle of historicism and taking into account the tendencies of the world economy in the market of livestock products.
\end{abstract}

\section{Introduction}

In the Russian Federation, various dominant branches of animal husbandry develop with regards to the natural and climatic conditions, which has led to the specialization of animal breeding in individual economic zones, regions within the Federal Districts. Due to territorial features, it is more profitable and convenient for regions to raise certain types of livestock. Understanding the preferred animal breeding direction based on territorial division helps agricultural producers to use natural and other resources more efficiently and rationally and to receive regular income from livestock products manufacturing and processing.

In the world livestock market, the leading positions are occupied by such industrialized countries as the USA, Canada, Northern Europe, Australia, New Zealand. Analysis of the developmental state of animal breeding in these countries has led to the conclusion that the increase in the volume of production in animal breeding and livestock productivity in these countries was caused by the combination of industrial technologies and integration of natural factors in the placement of animal breeding. For example, a significant part of beef cattle in these countries are raised year-round on natural pastures, which benefits cheap, high-quality and competitive products due to cheap pasture feed and minimal capital expenditures. The result is high productivity of dairy and beef cattle. For example, in the USA, Holland, Denmark, Sweden, the milk yield per cow is more than 8-9 thousand $\mathrm{kg}$ of milk annually.
The growth of animal productivity and the use of industrial production technologies in poultry farming, pig breeding and dairy farming mainly caused by large agricultural enterprises resulted in a stable growth dynamics and high competitiveness of products in these industries over the past 10 years [1,2]. At the same time, there is a downward trend in the livestock industry. Thus, over the same period, beef production decreased by $6.7 \%$ and milk production - by $0.5 \%$. The food security threshold in reference to the production of meat and meat products is higher than the established value, and in reference to the production of milk this threshold has not yet been reached. Thus, by 2019, taking into account reserves, the share of home production was $83.1 \%$ (with a threshold value of $90 \%$ ), and the share of imports was $16.9 \%$. Therefore, it is necessary to intensify the development of dairy and beef cattle breeding in all categories of farms based on a combination of natural climatic and internal factors in the process of production organization. The importance of livestock industries development is further enhanced by the fact that, according to researchers, in rural areas, livestock industries provide permanent jobs and contribute to the sustainable development of rural areas $[3,4]$.

\section{Materials and methods}

The object of the research was the livestock industries, the state and level of their development, as well as trends and factors affecting the efficiency of livestock farming

\footnotetext{
* Corresponding author: ilgizar-gg@mail.ru
} 
in the Russian Federation. The basis of the study and materials for the analysis were the official data of Rosstat, the Ministry of Agriculture of the Russian Federation. During the research, the following general logical research methods were used: analysis, synthesis, comparison, abstraction, generalization, as well as systemic and comparative, analytical and economicstatistical analysis.

\section{Results}

In the Russian Federation as a whole and in the Republic of Tatarstan in particular, the most developed branch of animal husbandry is cattle breeding being the largest, most productive and universal industry. This industry provides permanent jobs in agriculture, stable production volumes and the flow of funds for the development of production in agricultural enterprises. According to the research results [5-8], the following can be noted:

1. Dairy farming mainly develops in suburban areas located closer to industrial centers and large cities. If enterprises are located far from industrial centers, then large milk producers should have processing facilities in order to turn non-transportable products into transportable ones (butter, cheese, milk powder, etc.) and create added value for themselves as much as possible. If we analyze by region, we can see that in the North Caucasus, the Volga region, the Chernozem region agricultural enterprises mainly develop dairy cattle breeding. The northern regions, the Urals and the Far East are also leading in terms of the number of cattle.

2. One of the leaders in milk production is the Republic of Tatarstan, which produced $7 \%$ of all milk in the Russian Federation in 2020, and $19.6 \%$ of the total production in the Volga Federal District. Therefore, the development of the dairy cattle breeding industry is of great importance. Thus, according to the Ministry of Agriculture of the Republic of Tatarstan, in 2020 alone, 16 dairy complexes were put into operation in the Republic of Tatarstan for a total number of livestock of 6,418 heads, of which 5 complexes were designed for 500 and more milking herds. And for 2021, investment projects on the construction of more than 30 dairy complexes, out of which 14 are designed for keeping from 1,000 heads to 3,600 heads of milking herds, have been approved.

3. Beef cattle breeding is collateral to dairy farming. Growing and fattening of cattle has been significantly developed in the regions of the North Caucasus (Stavropol Krai, Rostov Region), as well as in the Volga Region (Saratov, Volgograd and Astrakhan Regions) and in the South Urals (Orenburg Region). Areas in which milk is the determining direction of cattle breeding, and meat is an accompanying one are as follows: Krasnodar Krai, regions of the Central Black Earth Zone, parts of the Urals, the Volga region and Western Siberia.

4. Pig breeding plays the role of the main supplier of meat to the domestic food market. The reason for this is the early maturity and fertility of pigs and the high turnover of working capital. The pig industry is well developed in the Volga region, the center of the
Chernozem region. The main part of the feed ration of pig breeding consists of compound feed, root crops and concentrates. Therefore, the development of this industry is possible where sugar beet, sunflower and corn, and grain feed crops are mainly growing. And they, in turn, can only be grown on arable land. Therefore, in these regions, crop rotations with a given set of crops should prevail on arable land.

5. Sheep breeding in Russia in the last 30 years has been the most susceptible to the processes of agricultural production reformation and is more likely to suffer from this. However, the development of small businesses and households contributed to the development of this industry at a moderate pace. The regions where large sheep herds are concentrated include: the North Caucasus, the South Volga region and the south of Western Siberia. Sheep meat is in great demand among Muslims (they live in the North Caucasus and Central Russia). In addition to meat, sheep are raised in order to obtain woolen fiber being the most valuable industrial raw material. The concentration of sheep breeders is high in the regions of steppe and dry steppe zone, that is, in the arid eastern part of the North Caucasus. In the last 20-30 years, sheep breeding in Russia has experienced a significant decline in livestock and the proportion of livestock products.

6. The role of the most dynamic livestock industry belongs to the poultry industry. Poultry farms are located throughout the country thereby providing the population with dietary meat and eggs. In Russia, the share of poultry meat in the diet is about $40 \%$ of all meat consumption. The main species of the total poultry population is chickens $(90 \%)$. The leading role in this industry belongs to the North Caucasus, Central Chernozem and Volga regions.

Thus, the branches of animal breeding have a certain territorial dispersion and find development in small, medium and large agricultural formations. Under climatic conditions that allow large quantities of fodder crops and fodder grain to be grown, intensive livestock holding is possible. Consequently, we can conclude that animal breeding is in the scope of the crop industry. That is, the livestock industry is dependent on the fodder base. The largest feed consumption comes from cattle breeding, in particular dairy farming. At the same time, the Russian Federation has huge areas of natural land in the form of hayfields and pastures (Table 1).

The total area of pastures and hayfields out of the total area of agricultural land was, as of January 1, 2020, $92,415.5$ thousand hectares, or $41.6 \%$. The largest areas of natural pastures were concentrated in the Southern $(13,969$ thousand hectares), Privolzhsky $(13,866.6$ thousand hectares) and Siberian $(15,087.3)$ federal districts. The largest livestock population was in the North Caucasian, Volga, Ural and Siberian federal districts. Consequently, the regions of the Southern Federal District should increase the production of livestock, primarily beef cattle.

Table 2, according to Rosstat, shows data on the number of livestock starting from the year1990 up to 2019. The data show that the number of farm animals in the categories of all farms compared with the pre-reform 
period (1990), has sharply decreased. Specifically, the number of cattle decreased by 3 times, cows by 2.6

times, pigs by 1.5 times, sheep and goats by 2.6 times.

Table 1. Area of agricultural land by federal districts of the Russian Federation, thousand hectares

\begin{tabular}{|c|c|c|c|c|c|c|}
\hline \multirow{2}{*}{ Federal district } & \multicolumn{5}{|c|}{ Land area by type } & Total area \\
\cline { 2 - 6 } & Layland & Perennial plantings & Pastures & Plowing & Hayfields & \\
\hline Central & 429.9 & 530 & $5,876.4$ & $23,849.6$ & $2,577.4$ & $33,263.3$ \\
\hline Northwestern & 241.4 & 121.5 & $1,239.6$ & 3,422 & $1,801.4$ & $6,825.9$ \\
\hline Southern & 33.2 & 333.4 & 13,969 & $18,519.6$ & 873.2 & $33,728.4$ \\
\hline North Caucasian & 23.2 & 174.5 & 5717.2 & $5,624.2$ & 553.5 & $12,092.6$ \\
\hline Privolzhsky & 860.1 & 367 & $13,866.6$ & $36,266.1$ & $3,671.7$ & $55,031.5$ \\
\hline Ural & $1,042.3$ & 106 & $3,796.4$ & $8,234.3$ & $3,177.5$ & $16,356.5$ \\
\hline Siberian & 882.8 & 201.8 & $15,087.3$ & 22,671 & $7,009.1$ & 45,852 \\
\hline Far Eastern & $1,417.5$ & 85.8 & $8,845.8$ & $4,102.3$ & $4,353.4$ & $18,804.8$ \\
\hline Total for RF & $4,930.4$ & 1,920 & $68,398.3$ & $122,689.1$ & $24,017.2$ & 221,955 \\
\hline
\end{tabular}

Source - Rosreestr data as of January 1, 2020

Table 2. Change in the number of farm animals in the Russian Federation (thousand heads)

\begin{tabular}{|c|c|c|c|c|c|c|c|c|c|c|}
\hline $\begin{array}{l}\text { Types of } \\
\text { livestock }\end{array}$ & 1990 & 2000 & 2010 & 2015 & 2016 & 2017 & 2018 & 2019 & \multicolumn{2}{|c|}{$\begin{array}{l}\text { In \% of the } \\
\text { year } 2019 \text { to }\end{array}$} \\
\hline \multicolumn{9}{|c|}{ Farms of all categories } & 2000 & 2015 \\
\hline Cattle & 57.043 .0 & 27.519 .8 & 19.793 .9 & 18.620 .9 & 18.346 .1 & 18.294 .2 & 18.151 .4 & 18.126 .0 & 65.9 & 97.3 \\
\hline cows & 20.556 .9 & 12.742 .6 & 8.713 .0 & 8.115 .2 & 7.966 .0 & 7.950 .6 & 7.942 .3 & 7.964 .2 & 62.5 & 98.1 \\
\hline Pigs & 38.314 .3 & 15.824 .4 & 17.251 .4 & 21.405 .5 & 21.924 .6 & 23.075 .5 & 23.726 .6 & 25.163 .2 & 159.0 & 117.6 \\
\hline $\begin{array}{l}\text { Sheep and goats, } \\
\text { total }\end{array}$ & 58.194 .9 & 14.961 .9 & 21.733 .7 & 24.606 .5 & 24.716 .9 & 24.389 .1 & 23.129 .3 & 22.617 .6 & 151.2 & 91.9 \\
\hline sheeps & 55.242 .1 & 12.730 .5 & 19.676 .1 & 22.443 .0 & 22.662 .4 & 22.347 .3 & 21.136 .4 & 20.655 .0 & 162.2 & 92.0 \\
\hline goats & 2.952 .8 & 2.231 .4 & 2.057 .6 & 2.163 .5 & 2.054 .5 & 2.041 .8 & 1.992 .9 & 1.962 .6 & 88.0 & 90.7 \\
\hline Horses & 2.618 .4 & 1.622 .2 & 1.284 .2 & 1.240 .6 & 1.216 .4 & 1.238 .6 & 1.283 .0 & 1.310 .9 & 80.8 & 105.7 \\
\hline Paultry & 659.808 & 340.665 & 449.711 & 543.914 & 550.169 & 555.827 & 541.447 & 544.691 & 159.9 & 100.1 \\
\hline Reindeer & 2.260 .6 & 1.197 .0 & 1.626 .2 & 1.764 .4 & 1.787 .6 & 1.838 .7 & 1.779 .9 & 1.734 .4 & 144.9 & 98.3 \\
\hline Rabbits & 3.354 .1 & 1.276 .7 & 2.773 .3 & 3.749 .8 & 3.625 .7 & 3.744 .7 & 3.562 .1 & 3.587 .6 & 281.0 & 95.7 \\
\hline $\begin{array}{l}\text { Bee colonies, } \\
\text { thousand pieces }\end{array}$ & 4.502 .6 & 3.473 .9 & 3.018 .9 & 3.425 .4 & 3.317 .0 & 3.182 .4 & 3.093 .9 & 2.982 .5 & 85.9 & 87.1 \\
\hline
\end{tabular}

Analysis of the world economies in terms of manufacturing core products shows that these economies mainly include industrialized countries such as the USA, Canada, Northern Europe, Australia, New Zealand. It is worth noting that the climate of Australia, New Zealand and partly in the United States enables to graze livestock on pastures all year round. Most of the beef cattle in these countries are raised year-round on natural pastures, which contributes to obtaining cheap, high-quality and competitive products due to cheap pasture feed and minimal capital expenditures.

Intensive dairy farming in these states is carried out due to favorable climatic conditions and high technological levels. The result is a high productivity of dairy cattle. For example, in the USA, Holland, Denmark, Sweden, the milk yield per cow is more than 8-9 thousand $\mathrm{kg}$ of milk annually. While in India, which is leading in terms of gross milk yield in the world, one cow gives no more than 3 thousand $\mathrm{kg}$ of milk per year.

Breeding livestock for meat is less resource-intensive in general as well as in terms of feed consumption. Consequently, meat herds can be fed exclusively on natural steppe pastures. In this industry, the leaders are countries that have large sparsely populated steppe regions. Such natural pastures are possessed by such countries as: Brazil, China, USA, Argentina, Ethiopia, Sudan, Mexico, Russia, Australia and others. A significant part of the meat for the food market in the world is supplied by sheep farms. The largest number of sheep is raised in Australia, China, New Zealand, India, Turkey, Kazakhstan [8].

The domestic agricultural sector is represented by all major livestock sectors. However, the most important area of the livestock industry is cattle breeding. The main reason for raising cattle is the production of milk and meat. The demand for milk in the Russian market is $90 \%$ satisfied by domestic producers $[9,10]$.

Despite the fact that the livestock of the main types of farm animals has sharply decreased and has not reached the pre-reform level, the production of livestock products over the past 10 years has had a stable growth trend (Table 3). However, structurally, there are certain changes concerning some types of products. Thus, the volume of beef production decreased by $6.7 \%$ and milk production - by $0.5 \%$.

Food security in terms of livestock products is achieved if the share of their own production on the domestic market in the total volume of commodity resources (including carry-over stocks) is as follows: meat and meat products (in terms of meat) - at least $85 \%$, milk and dairy products (in terms of milk) - at least $90 \%$.

Since 2014, Russia has managed to reach the minimum food safety threshold for meat. The food security doctrine states that the volume of domestic meat must be at least $85 \%$. If in 2019 self-sufficiency was 
$93.9 \%$, then by the end of 2020 it was expected to be at the level of $96 \%$ (Table 4 ).

Thus, for the production of meat and meat products in our country, there is an opportunity to increase the volume of product supplies not only to the domestic market but also to the foreign market, especially for poultry and pork. And the production of beef should ensure its production in the first place, to meet the demand on the domestic market.

Table 3. Production of basic livestock products in the Russian Federation (farms of all categories), thousand tons [12]

\begin{tabular}{|l|c|c|c|c|c|c|c|c|c|c|c|}
\hline \multicolumn{1}{|c|}{ Product } & 2010 & 2011 & 2012 & 2013 & 2014 & 2015 & 2016 & 2017 & 2018 & 2019 & $\begin{array}{c}2019 \text { in } \\
\% \text { to } 2010\end{array}$ \\
\hline $\begin{array}{l}\text { Livestock and } \\
\text { poultry for slaughter } \\
\text { (in live weight) }\end{array}$ & 10.549 & 10.955 & 11.596 & 12.189 & 12.843 & 13.397 & 13.896 & 14.513 & 14.880 & 15.164 & 143.7 \\
\hline $\begin{array}{l}\text { including: } \\
\text { - cattle }\end{array}$ & 3.028 & 2.857 & 2.874 & 2.864 & 2.855 & 2.820 & 2.777 & 2.738 & 2.798 & 2.827 & 93.3 \\
\hline - pigs & 3.097 & 3.207 & 3.292 & 3.615 & 3.812 & 3.951 & 4.329 & 4.550 & 4.797 & 5.032 & 162.5 \\
\hline - poultry & 3.878 & 4.338 & 4.875 & 5.152 & 5.585 & 6.039 & 6.191 & 6.618 & 6.671 & 6.709 & 173.0 \\
\hline Milk & 31.508 & 31.204 & 31.197 & 29.865 & 29.995 & 29.887 & 29.787 & 30.185 & 30.612 & 31.351 & 99.5 \\
\hline
\end{tabular}

Table 4. Resources and use of meat and meat products in the Russian Federation*

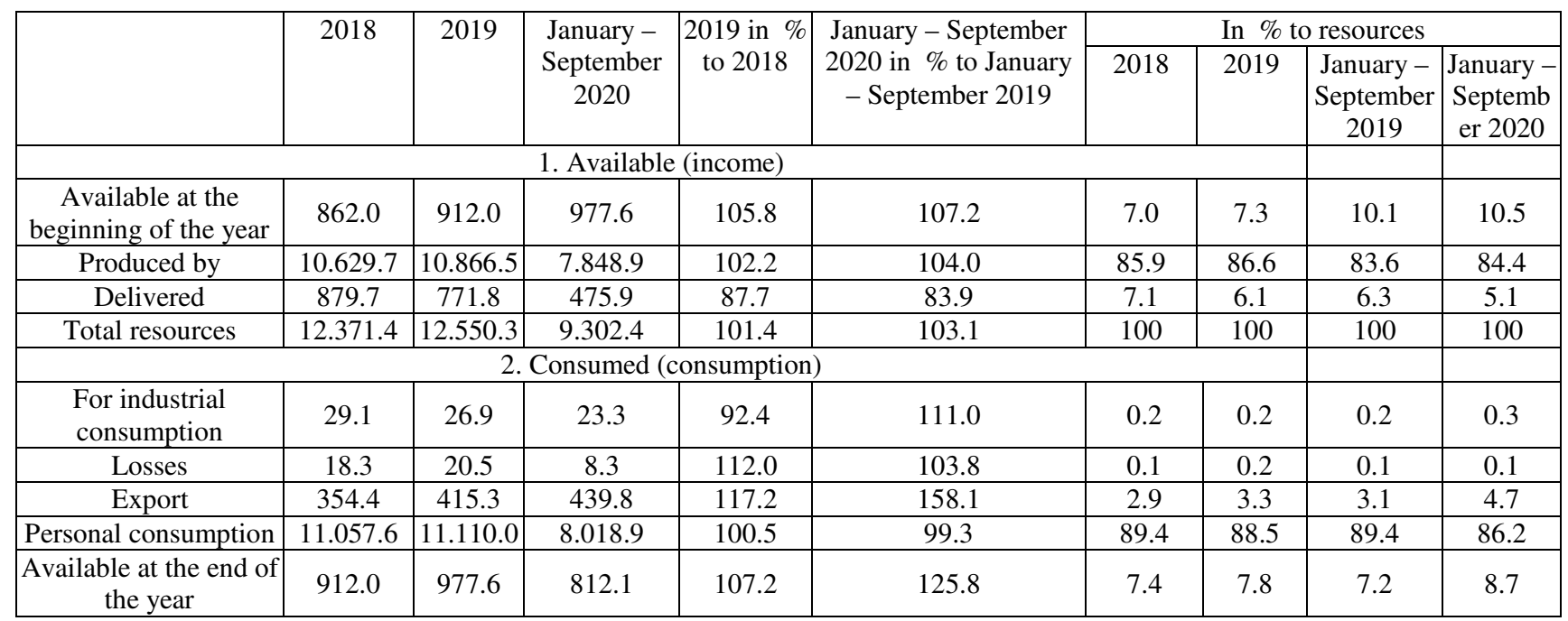

*according to the official data of Rosstat (updated 03.12.2020)

The rate of milk and dairy products production over the past 3 years has had an upward trend (Table 5). However, the growth rate of imports exceeds the growth rate of domestic production, and the share of domestic production, including reserves, by 2019 amounted to $83.1 \%$, which was clearly below the threshold value established by the Food Security Doctrine.

Table 5. Resources and use of milk and dairy products in the Russian Federation *

\begin{tabular}{|c|c|c|c|c|c|c|c|c|c|}
\hline & \multirow[t]{2}{*}{2018} & \multirow[t]{2}{*}{2019} & \multirow{2}{*}{$\begin{array}{c}\text { January - } \\
\text { September } \\
2020\end{array}$} & \multirow{2}{*}{$\begin{array}{c}2019 \text { in } \% \\
\text { to } 2018\end{array}$} & \multirow{2}{*}{\begin{tabular}{|c|} 
January - \\
September 2020 in \\
$\%$ to January - \\
September 2019
\end{tabular}} & \multicolumn{4}{|c|}{ In $\%$ to resources } \\
\hline & & & & & & 2018 & 2019 & \begin{tabular}{c|} 
January - \\
September \\
2019 \\
\end{tabular} & \begin{tabular}{|c|} 
January - \\
September \\
2020 \\
\end{tabular} \\
\hline \multicolumn{10}{|c|}{ 1. Available (income) } \\
\hline $\begin{array}{c}\text { Available at the } \\
\text { beginning of the year }\end{array}$ & 1.638 .9 & 1.680 .1 & 1.798 .9 & 102.5 & 107.1 & 4.2 & 4.2 & 5.5 & 5.6 \\
\hline Produced by & 30.611 .1 & 31.360 .4 & 24.910 .1 & 102.4 & 102.7 & 79.0 & 78.9 & 78.7 & 78.3 \\
\hline Delivered & 6.493 .0 & 6.727 .8 & 5.122 .8 & 103.6 & 105.3 & 16.8 & 16.9 & 15.8 & 16.1 \\
\hline Total resources & 38.743 .0 & 39.768 .3 & 31.831 .8 & 102.6 & 103.4 & 100 & 100 & 100 & 100 \\
\hline \multicolumn{10}{|c|}{ 2. Consumed (consumption) } \\
\hline $\begin{array}{l}\text { For industrial } \\
\text { consumption }\end{array}$ & 2.903 .3 & 2.992 .3 & 2.352 .5 & 103.1 & 101.6 & 7.5 & 7.5 & 7.5 & 7.4 \\
\hline Losses & 31.3 & 38.0 & 16.3 & 121.4 & 105.8 & 0.1 & 0.1 & 0.1 & 0.1 \\
\hline Export & 576.3 & 611.0 & 506.0 & 106.0 & 112.7 & 1.5 & 1.5 & 1.5 & 1.6 \\
\hline Personal consumption & 33.552 .0 & 34.328 .1 & 26.735 .5 & 102.3 & 103.4 & 86.6 & 86.4 & 83.9 & 83.9 \\
\hline $\begin{array}{l}\text { Available at the end of } \\
\text { the year }\end{array}$ & 2.903 .3 & 2.992 .3 & 2.352 .5 & 103.1 & 101.6 & 7.5 & 7.5 & 7.5 & 7.4 \\
\hline
\end{tabular}

*according to the official data of Rosstat (updated 03.12.2020) 


\section{Conclusion}

Analysis of the state and level of livestock industries development in the Russian Federation and the dynamics of core products manufacturing leads to the following conclusions:

1) The number of livestock over the post-reform period (after 1990) has sharply decreased, with the exception of peasant (private) farms, which are increasing both livestock and production volumes.

2) Volumes of livestock products manufacturing by the following types: poultry meat, pork has a steady growth trend for 2010-2019. And the volumes of cattle meat and milk production are decreasing. In general, for poultry and livestock meat, the level of self-sufficiency in this type of product significantly exceeds the threshold value determined by the Food Security Doctrine. For milk, this level is only $83.1 \%$ (2019), instead of $90 \%$, which is well below the threshold.

3) The volume of imports of core livestock products also had an upward trend with the exception of milk, whose imports increased in $2015-2019$ by $8.4 \%$. Poultry and pork have the leading positions in the structure of meat and meat products export. In the future, these areas should be considered as a potential for increasing export supplies.

4) Analysis of the level of livestock industries development in the world shows that competing positions in the world market are occupied by USA, Canada, Northern Europe, Australia, New Zealand. These countries successfully combine the use of both internal factors (innovative technologies for keeping and feeding livestock in automated complexes) and natural factors (grazing livestock on natural pastures when fattening cattle without the construction of capital buildings).

5) In large livestock complexes, it is necessary to expand the scope of digital technology products in order to improve the quality of products and eliminate the "human factor".

In general, based on the foregoing, it follows that agricultural enterprises, small businesses and households should fully support and provide various forms of state support to increase the production of dairy and beef cattle breeding. When developing programs for the export increase of agricultural products, measures of state assistance for the export of pig and poultry products should be developed.

\section{References}

1. I.G. Gainutdinov, A.F. Kosmodemyanskaya, Science Diary, 2(26) (2019)

2. F.N. Mukhametgaliev, D.I. Fayzrakhmanov, G.S. Sharafutdinov et al., Bull. of Kazan State Agrar. Univ., 4 (2006)

3. I.G. Gainutdinov, S.A. Sharipov, Agro-industrial complex: economics, management, 3(53-56) (2008)

4. S.A. Sharipov, Agroindustrial Complex: Economics, Management, 6(15-19) (2009)

5. F. Mukhametgaliev, L. Sitdikova, F. Avkhadiev et al., BIO Web of Conf., 17 (2020)

6. L. Mikhailova, F. Avkhadiev, N. Asadullin et al., BIO Web of Conf., 27, 00095 (2020)

7. F. Avkhadiev, N. Asadullin, I. Gainutdinov et al., BIO Web of Conf., 27, 00100 (2020)

8. P.I. Zelenkov, A.I. Barannikov, A.P. Zelenkov, Phoenix (2018)

9. Retrieved from: https: //piginfo.ru/news/rossiyskiyrynok-myasa-2019-tendentsii-i-prognozy/ (Accessed 04.24.2021)

10. Rosstat website. Retrieved from: https://rosstat. gov.ru/folder/11188?print=1 (Accessed 04.23.2021) 